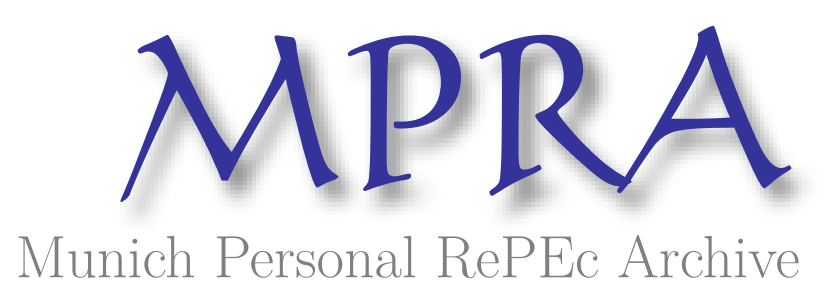

\title{
The US dollar, the euro, and the yen: An evaluation of their present and future status as international currencies
}

Beckmann, Rainer and Born, Jürgen and Kösters, Wim

2001

Online at https://mpra.ub.uni-muenchen.de/5274/

MPRA Paper No. 5274, posted 11 Oct 2007 UTC 


\section{IFW ${ }_{\text {Eutitut für }}^{\text {Inston }}$

\section{Diskussionsbeiträge}

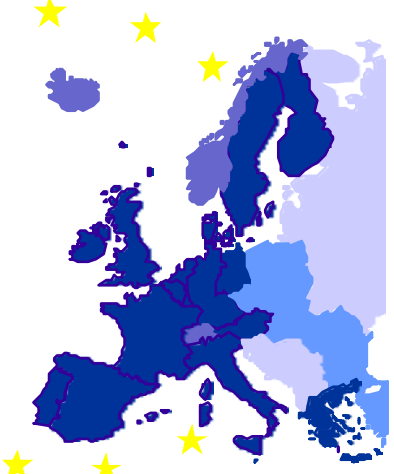

Rainer Beckmann, Jürgen Born and Wim Kösters

The US dollar, the euro, and the yen: An evaluation of their present and future status asinternationalcurrencies 
AnschriftderAutoren:

RainerBeckmann

GC $3 / 148$

Tel. :0049-(0)234/32-22776

rainer.beckmann@ruhr-uni-bochum.de

JürgenBorn

GC $3 / 146$

Tel.:0049-(0)234/32-22889

juergen.born@ ruhr-uni-bochum.de

Prof. Dr.WimKösters

GC $3 / 150$

Tel.:0049-(0)234/32-28888

wim.koesters@ ruhr-uni-bochum.de

Ruhr-UniversitätBochum

FakultätfürWirtschaftswissenschaft

LehrstuhlfürTheoretischeVolkswirtschaftslehrel

Universitätsstraße 150

D-44780Bochum

Bochum

2001

Impressum:

\footnotetext{
EN Institut für

L $\sqrt{ }$ Europäische Wirtschaft

FakultätfürWirtschaftswissenschaftderRuhr-UniversitätBochum

GeschäftsführenderDirektor:Prof.Dr.WimKösters FakultätfürWirtschaftswissenschaft Ruhr-UniversitätBochum Universitätsstraße 150 GebäudeGC3/150

D-44780Bochum
}

Telefon: $(0234) / 32-28888$

Telefax:(0234)/32-14258 


\title{
The US dollar, the euro, and the yen: An evaluation of their present and future status as international currencies
}

\author{
by \\ Rainer Beckmann, \\ Jürgen Born and \\ Wim Kösters
}

Ruhr-Universität Bochum

2001

forthcoming in:

Klenner, W. and H. Watanabe (2001): Globalization and regional dynamics: East Asia and the European Union from the Japanese and the German perspective, Springer-Verlag, Heidelberg. 


\section{Introduction}

During the entire post World War II period the international monetary and financial system has been shaped to a significant degree by the United States of America having the status of the leading economic power. An impressive indication of this superiority is the US dollar acting as the only currency of outstanding international importance. Despite the fact that the Deutsche mark and the Japanese yen internationally gained ground in the course of the last two decades the US dollar was ahead by a wide margin and the US acted as the only economy that had to a considerable degree to cope with both the beneficial and the disadvantageous effects emanating from the issuance of an international currency. The process of European integration and especially the introduction of the euro as the single currency for up to now 12 member countries of the EU in 1999 may alter this clear currency hierarchy. The euro area is comparable in size to the US with respect to GDP and even exceeds the US regarding the share in world trade. Thus questions arise of whether the international monetary system turns out to be bipolar in the long run or whether the yen can also play its part.

No accepted theoretical framework is yet existent to clarify which conditions will be sufficient to reach the status of a major international currency. Traditionally, trade relations, GDP but also inertia with respect to the use of a certain currency as a medium of exchange and a store of value have been mentioned as factors to explain the international role of a currency. In view of globalization with worldwide almost completely liberalized capital flows liquid and sophisticated financial markets are now overwhelmingly seen as yet another crucial precondition for a currency to play a significant international role. This is especially important after the start of EMU making the US and the euro area economies of comparable economic size. A deeper look at the developments of European financial markets is then indispensable since their pure aggregation may be deceptive in the light of still prevailing barriers to truly integrated financial markets in Europe. The paper proceeds as follows. In section 2 the functions, benefits, and costs of a leading international currency are discussed. In section 3 key determinants for the continuous dominance of the US dollar are analysed in order to assess the sustainability of this regime. Since it turns out that highly developed financial markets are of special importance section 4 takes a closer look at the integration of European financial markets emphasizing the enormous structural changes that came about since the euro has been established in 1999. The comparatively weak international status of the yen, currently ranked third, is briefly sketched in section 5. In the last section we sum up our findings by trying to assess how the future currency regime most probably will look like.

\section{Functions, benefits, and risks of an international currency}

A sound institutional frame allowing for a dynamic development of international financial markets in the future requires an appropriate design of the underlying currency regime. Under the Bretton Woods system fixed exchange rates to be defended within narrow limits made monetary authorities and national governments play a dominant role. Today, in a world of almost completely free international capital movements and exceptionally high turnovers on foreign exchange markets that sum up to a daily average of 1.5 trillion dollar (BIS, 1999), central banks may no longer be capable of successfully intervening on these markets. In a study on the continuously decreasing success of foreign exchange market interventions by central banks Anna J. Schwartz states: "Experience has disillusioned them." (Schwartz, 2000, p. 1). Billions of dollars are rapidly moved and removed from one place to another. Countries being particularly dependent on (short term) 
foreign capital can easily be faced with drastic (long term) economic consequences.

Especially short-term oriented investors that are repeatedly blamed for their alleged destabilizing speculation, may withdraw their capital as soon as possible if expected risk-adjusted returns fall in one country and rise somewhere else. Governments, therefore, are forced to adjust their economic policy to avoid a sudden outflow of foreign capital resulting from unsustainable policies in the respective country. ${ }^{1}$ In this sphere of the "new structure of power" (Cohen, 1998) governments have to share their monetary power with international financial markets, the latter now serving as a strong monitor for national economic policies and reducing their range of activities. $^{2}$

\section{Functions of an international currency}

The change in the international financial framework sketched above calls for a more detailed analysis. In particular, the decisions of participants in international markets to use a certain currency are of interest. In table 1 three key functions of the use of a currency outside the issuing country are presented. The functions of an international currency correspond to the classical functions of (national) money: medium of exchange, unit of account, and store of value. In addition, the private use of money can be distinguished from its official use.

Table 1: Functions of an international currency

\begin{tabular}{l|ll}
\hline Function & Private use & Official use \\
\hline Medium of exchange & Vehicle currency & Intervention currency \\
Unit of account & Quotation currency & Pegging currency \\
Store of value & Investment/ Financing currency & Reserve currency \\
\hline
\end{tabular}

Source: Hartmann (1998) and Detken and Hartmann (2000).

Hartmann (1998) defines a currency to be an international one, if private or official agents that both reside abroad make significant use of at least one out of the six functions in table 1 . To get an overall view of a currencies' degree of internationalization one could be tempted to analyse each of the functions given in table 1. Yet, in this paper we focus on private currency use since on foreign exchange markets power shifted away from official action towards international market forces. So we primarily deal with the vehicle, the quotation, and the investment/financing functions of international currencies. The functions of a currency are of course intertwined rather than firmly separated. Therefore, it is not conducive to purely analyse each for the sake of completeness. Instead, the different functions concerning the private use of international currencies are selectively taken up during the discussion in sections 3 to 5 when discussing the respective role of the dollar, the euro, and the yen. ${ }^{3}$

\section{Benefits}

One major direct and indisputable economic benefit of the widespread international use of a currency in favour of the issuing country is international seigniorage. As soon as foreigners are willing to hold an international currency for transaction and portfolio purposes they exchange no

\footnotetext{
${ }^{1}$ During the 1997/98 currency crisis, for instance, Asia had to experience this. Some South-East Asian countries, though, recovered in terms of GDP growth rates in 1999 and 2000.

${ }^{2}$ Cohen adds to his view of a shifting structure of power that cross-border competition has not so much diminished as transformed the role of the state (Cohen, 1998, chapter 7).

${ }^{3}$ For a detailed investigation of each function see Hartmann (1998).
} 
interest-bearing money for their own interest-bearing securities, so that a net gain for the issuing central bank occurs. ${ }^{4}$ For the US this gain is estimated to amount to about $0.1 \%$ of GDP per year. Another economic benefit is a liquidity premium on interest rates, which Portes and Rey (1998, p. 309) label "another, often neglected source of seigniorage". According to them the comparatively high share of US government securities held by non-residents denotes a disproportionate international demand for dollar-denominated US debt. Because of this, i.e. the US dollar serving as an international investment currency, interest payments for outstanding debt are lower. Portes' econometric work as well as estimates from market participants show that the interest rate liquidity premium amount to at least 25 basis points adding another estimated yearly flow of $0.1 \%$ of GDP to the seigniorage mentioned above (Portes, 2000).

Further efficiency gains result from liquid and sophisticated financial markets in the domain of the currency predominantly used. In that case transaction costs in foreign exchange and securities markets tend $\mathrm{b}$ be lower and, in addition, a broad maturity spectrum and a wide array of innovative financial products improve the risk-management and the unbundling of risks for private actors. In their "big euro" scenario Portes and Rey (1998) expect the benefits for the euro area resulting from a reduction of transaction costs to be equal to the combined gains of seigniorage and "liquidity discount", amounting to a further $0.2 \%$ of GDP..$^{5}$ Added together, annual benefits of $0.4 \%$ of GDP may solely be attributed to the role of an outstanding international currency (corresponding to a "big dollar" or "big euro" scenario).

Some examples may illustrate these gains. Within the country that issues an international currency consumers face lower transaction costs for exchanging cash due to relatively narrow bid-ask spreads. Companies gain from a widely accepted invoicing currency by reducing their costs of currency conversion and exchange rate risk management. Hedging costs deriving from foreign exchange exposures (claims and liabilities) have then to be born by their counterparts residing in countries having no international currency. A well known example is the disadvantage of Airbus Industries with respect to Boeing in this field. Existing market rules force Airbus Industries to invoice its products in US dollar whereas its costs are mainly denominated in euro. Unanticipated fluctuations in the euro-dollar rate thus inevitably lead to volatility of Airbus profits since the dollar proceeds have to be exchanged for euro. Therefore, risk exposure or hedging costs are solely the problem of Airbus Industries - a lucid competitive advantage for Boeing.

Another example relates to the competitive position of the financial services industry. Here microeconomic benefits result from the privilege of large international investment banks to be located in a country having an international currency. Empirical evidence shows that financial institutions residing within the country that issues an international currency dominate the international primary bond market. The Bank for International Settlement (BIS) presents market shares of bookrunners whose nationality matches the currency of issue and compares these figures with the market shares of bookrunners that share the nationality with the borrower, both for the EU-11 and the US. The results for 1996-98 reveal that "historically the nationality of the underwriter of an international bond has been more closely associated with the currency in which the bond is issued than with the nationality of the borrower." (BIS, 2000, p. 131). Again, this means a competitive advantage for the US, i.e. for their corporate financial services industry.

\footnotetext{
${ }^{4}$ The use of Deutsche mark for example is presently widely spread all over Middle- and Eastern Europe. It serves as a second national currency in Bosnia and Montenegro. Therefore, the Deutsche Bundesbank earned parts of its profit abroad.

${ }^{5}$ In the "big euro" scenario the US dollar only dominates the dollar-yen market, whereas the euro is dominant on the euro-yen and the euro-dollar markets.
} 
According to Steinherr "in no other industry has the United States been as resolutely superior as in the financial industry." (Steinherr, 1998, p. 29).

However, trying to quantitatively assess those indirect economic benefits is very difficult. Similar to the role of English as a lingua franca, the widespread use of the US dollar as an international vehicle, quotation, and investment currency contributes to the worldwide establishment of American practices of business, capital market rules and accounting standards. Feldstein holds the view that "the Anglo-American common law rules, corporate governance principles and accounting standards improve the efficiency with which capital is invested." (Feldstein, 2000a, p. 1). As a consequence of the growing acceptance of this position other countries trying to set their own rules might soon be confronted with penalties from foreign investors since their regulations are not in line with international, i.e. American arrangements. Therefore, the role of the dollar as the dominant international currency helps the US to make their own regulations international economic standards while the costs of adjusting to these rules are imposed on all other countries.

\section{Risks}

In turning to the risk side of having an international currency mainly two issues emerge. First, negative welfare effects of supplying an international currency may arise if the national central bank gets under pressure to serve as an international lender of last resort. Being the provider of reserves to the international financial system the prevention of a collapse of a major single bank or a crisis of the whole banking system may turn out to be costly. At the same time, however, this confers political power on the international lender as shown e.g. by the "key role of the US Treasury alongside the IMF in the Mexican crisis, the Asian crisis, and Brazil." (Portes, 2000, p. 2).

Second, the large quantity of an international currency held outside the country of issuance may blur domestic monetary policy. In 1995, for instance, $70 \%$ of total dollar cash (outside banks) vs. $20 \%$ of total Deutsche mark cash was held abroad. ${ }^{6}$ The demand for money by non-residents originating e.g. from dollarized economies in Latin America like Brazil or Argentina - is potentially more unstable than the domestic money demand. Monetary strategies of many central banks (among them the ECB) put strong emphasis on a reliable forecast of monetary aggregates. Shifts in and out of an international currency mainly by non-residents will bring about a higher volatility of shifts in the quantity of money and thus cause problems for the conduct of a monetary policy oriented towards price level stability. It has been exactly for this reason that the Deutsche Bundesbank and the Bank of Japan were hesitant to allow for a wider international use of their currencies. The Bundesbank was afraid of inflationary potentials that could unfold in a scenario of a depreciating Deutsche mark in the wake of strong and abrupt sales of this currency. Under such circumstances monetary policy decisions may become unintentionally constrained by the need to discourage abrupt switches into other currencies.

Yet, from a political perspective, the omnipresence of the dollar creates undisputable benefits for the US - besides the purely symbolic and psychological meaning of possessing a world currency. Several further political repercussions are pointed out by Cohen: "Domestically, the hegemon is better insulated from outside influence or coercion in formulating and implementing policy. Abroad, it is better able to pursue foreign objectives without constraint as well as to exercise a degree of influence or coercion to others." (Cohen, 1998, p. 128f).

To sum up, the status of an international currency indeed matters. Significant, not negligible gains have to be balanced against potentially small, more indeterminate losses. Recent policy clearly confirms that the US want to preserve their dominant position while the EU and East-Asia made a political effort, especially with respect to financial market liberalization and economic integration,

${ }^{6}$ These figures are presented in Rogoff (1998). 
to make the euro resp. the yen more competitive with the dollar. In Japan, for instance, even an official "Study Group for the Promotion of the Internationalization of the Yen" was formed in September 1999. Apparently, in the view of political authorities the potential gains would outweigh potential losses.

\section{The status quo: Factors determining the dominance of the US dollar}

From a historical perspective the dominance of the US dollar today partly can be explained by former accommodating institutional settlements. The transition from pound sterling to the US dollar as the leading international currency in the first half of the last century took place rather slowly and was finally pushed by the creation of the Bretton Woods System in 1944. Rey (1999) shows that pound sterling remained the dominant international currency as long as Great Britain's foreign trade exceeded the corresponding volume of the US. Despite the fact that already in 1870 the US had surpassed the UK in terms of economic size (measured by GDP) it took the dollar more than half a century to replace the pound as the international key currency. "Only after World War II did the exports of the US overtake significantly the exports of the UK. These data are consistent with our result that trade flows are the key determinants of internationalization of currencies, as opposed to economic size." (Rey, 1999, p. 26f).

According to Kindleberger (1973) the long transition period in which the pound started to loose its dominant role as international currency without being instantly replaced by the US dollar caused a vacuum of international leadership at the wake of the Great Depression in 1929. Neither the Bank of England nor the US Federal Reserve assumed the responsibility needed to fight instability on international financial markets. Not before the end of World War II the US had the power and the political will to design a new international financial order that eventually paved the way for an era of unprecedented economic growth. ${ }^{7}$

The Bretton Woods System institutionalised the role of the US dollar as the major international currency. In order to reduce financial instability as experienced during the Great Depression the classical Gold Standard was substituted by a fixed exchange rate regime pegging all currencies to the dollar and installing a dollar-gold link. Such regulations were perfectly in line with the widely accepted view that an institutional settlement allowing for active intervention would be most efficient to control volatile and erratic moves of markets. But the envisaged stabilizing effect of fixed exchange rates turned out to be a problem when rapid economic recovery in West Germany and Japan would have required consecutive devaluations of the US dollar. Because international coordination about adequate realignments failed due to diverging economic interests the sustainability of that regime was undermined. When the Bretton Woods system finally broke down in 1972 the new regime of floating exchange rates seemed to put an end to the privileged position of the US dollar. But even though the Deutsche mark and to a lesser extent the yen started to take over a few international currency functions (table 1) they never really threatened the profound dominance of the US dollar in this respect.

\section{Size, trade, and invoicing}

Following Rey's (1999) aforementioned argument, Britain's formerly high share in worldwide exports rather than its GDP accounted in great part for the international success of the pound sterling before World War II. But such a finding must be examined carefully before deriving

\footnotetext{
${ }^{7}$ Kunz (1995) points out that "geopolitical power depends on financial power, each of which supports the other." This interdependency has to be kept in mind when discussing the economics of international monetary and currency regimes.
} 
general conclusions. Taking a look at economic size and the share in international trade in 1999 (table 2) it stands out that the US share of world GDP (20.8\%) is larger than the respective numbers of the euro area $(15.5 \%)$ and Japan $(7.5 \%)$ whereas the euro area has a considerably higher share of world trade (19.5\%, excluding intra-European trade) than the US (15\%) as well as Japan $(8.5 \%)$. These trade figures are underlined by the fact that the euro area is more open $(17 \%)$ than the US (11\%) and Japan (9\%).

Table 2: Economic size, international trade, and openness 1999

\begin{tabular}{llll}
\hline & $\begin{array}{l}\text { Share of world GDP in } \\
\%\end{array}$ & $\begin{array}{l}\text { Share of world exports } \\
\text { in } \%\end{array}$ & $\begin{array}{l}\text { Openness: } \\
\text { Exports }^{\text {a) }} / \text { Imports }^{\text {a) }}\end{array}$ \\
\hline EU-11 & 15.5 & $19.5^{\text {b) }}$ & $17^{\text {b) }} / 15^{\text {b) }}$ \\
USA & 20.8 & 15 & $11 / 13$ \\
Japan & 7.5 & 8.5 & $9 / 8$ \\
\hline
\end{tabular}

Source: ECB (2000). a) As \% of GDP, averages 1997-99; b) Relating to extra-area trade flows.

Table 3: Invoicing of international trade

\begin{tabular}{llll}
\hline & 1980 & 1992 & $\mathrm{CI}^{\mathrm{b})} 1992$ \\
\hline EMS-5 $^{\text {a) }}$ & 31 & 33 & - \\
Deutsche mark & 14 & 15 & 1.4 \\
US dollar & 56 & 48 & 3.6 \\
Japanese yen & 2 & 5 & 0.6 \\
\hline
\end{tabular}

Source: McCauley (1997); more actual numbers are currently not available.

a) EMS-5: DEM, FRF, GBP, ITL, NLG; b) CI (coefficient of internationalization) $=$ trade

invoiced in currency $\mathrm{x}$, divided by trade of country with currency $\mathrm{x}$ as legal tender

Assuming that these relations remain rather stable over time and in line with Rey's assessment that trade flows are most important one might suggest that we are at the edge of a switch from the US dollar to the euro as the leading international currency. Yet, a completely different story is told by the invoicing behaviour of participants in international trade (table 3).

To reach an agreement about the unit of account used for an international transaction trade partners have three choices at their disposal: payment is carried out in the exporter's, the importer's or a third (vehicle) currency. If Grassman's Law (Grassman, 1973) would fit fully - i.e. trade tends to be invoiced in the exporter's currency - and if exports and imports would be balanced different currencies should reveal a similar coefficient of internationalization (CI). Though, the CI column of table 3 reveals huge differences: In 1992 the US dollar was used to denominate trade 3.6 times the value of US trade whereas the corresponding factor for the Deutsche mark was 1.4 and far below one for the yen. One has to concede that between 1980 and 1992 the estimated share of world trade invoiced in US dollar declined significantly but to a certain extent this can be explained by the drop in oil prices. ${ }^{8}$ Nevertheless, dollar invoicing remained on a high level of $48 \%$ for the last decade.

\footnotetext{
${ }^{8}$ See McCauley (1997). For a more detailed analysis of the invoicing behavior see Krugman (1992) and Cohen
} (1998). 
Up to now a high percentage of trade between the EU-11 and non-European countries has been invoiced in US dollars. A lot of raw materials like oil are traded almost exclusively in US dollar independent of the nationality of buyers and sellers. The relatively high share of US dollar invoiced trade implies that the use of the dollar in international trade does not reflect the foreign demand for US goods. Thus, a first important outcome of our analysis is that neither a country's absolute size nor its share of world trade are indicators sufficient to determine the international performance of its currency.

\section{Interaction on foreign exchange and securities markets}

In order to deepen the explanation of US dollar's supremacy Alogouskoufis, Portes, and Rey (1997) developed an innovative theoretical framework by incorporating the structure of international financial markets into the analysis. They approached the invoicing puzzle sketched above for the most part from a transaction costs perspective accentuating the interaction between private market participants on foreign exchange (forex) and securities markets. International financial markets have been subject to rapid changes in recent decades. Technological progress, financial innovations (partly due to improved theoretical models of finance, e.g. the theory of option pricing by Black and Scholes, 1973) and above all reduced regulations led to an upsurge in the transaction volumes of financial markets. Therefore, synergy effects between securities and forex markets became stronger. Within this framework official actions such as the management of currency reserves or the choice of a certain currency regime (table 1), e.g. exchange rate pegging, are of secondary importance.

On foreign exchange markets the US dollar has adopted the role of a global vehicle currency, i.e. it serves as the prevalent international medium of exchange. Table 4 shows that the US dollar accounted for more than $80 \%$ of the turnover on international foreign exchange markets in 1992 and extended this lead to $87 \%$ in 1998 with the Deutsche mark and the Japanese yen following by a share of $30 \%$ and $21 \%$, respectively (all figures out of $200 \%$, see note in table 4). Even all EMS currencies taken together accounted for a turnover considerably less than the dollar. These figures become even more impressive when excluding intra-European forex transactions: McCauley (1997) estimates the share of the US dollar to rise under the assumption of European Monetary Union from $83 \%$ to $92 \%$ in 1995 whereas the EMS currencies would drop from $70 \%$ to $56 \%$.

Table 4: Turnover on international foreign exchange markets in $\%$

\begin{tabular}{llll}
\hline & April 1992 & April 1995 & April 1998 \\
\hline EMS & 70 & $70 / 56^{*}$ & 63 \\
Deutsche mark & 40 & $37 / 31^{*}$ & 30 \\
US dollar & 82 & $83 / 92^{*}$ & 87 \\
Japanese yen & 23 & $24 / 26^{*}$ & 21 \\
\hline
\end{tabular}

Source: BIS (1999); *corrected for intra-EMS turnover, McCauley (1997); own calculations.

Because of two currencies involved in each transaction the total of shares sum up to $200 \%$.

This pattern of disproportionately high dollar shares on foreign exchange markets (similar in magnitude to the aforementioned invoicing behaviour) favours the trading of financial assets denominated in the "privileged" currency. In turn, a more liquid US dollar securities market strengthens the role of the US dollar as a vehicle currency. Thus, a virtuous circle arises and enhances the liquidity of both the foreign exchange and the securities markets. A drop in transaction costs is the major result but simultaneously also the ultimate cause for this feed-back 
dynamic. Alogoskoufis, Portes, and Rey (1997) developed an approach to analyse the potential of the euro in challenging the dollar's international supremacy. The nucleus of their influential analysis consists of financial market considerations emphasizing the interaction between foreign exchange and securities markets, while private invoicing behaviour, official reserve management, and currency pegging decisions are forced to adjust. A network of financial relations is then crucial in explaining the strong dollar shares. In a similar framework, special features of the "new economy" are analysed by Shapiro and Varian: "The value of connecting to a network depends on the number of other people already connected to it." (Shapiro and Varian, 1999, p. 174). These network externalities or demand-side economies of scale can only come up as long as a huge share of all transactions on foreign exchange markets is intermediated through one single currency (the dollar). Otherwise, it is hard to reach a critical degree of liquidity which is indispensable to realize the desired advantages in cost reduction.

\section{Financial market liquidity}

The continuous strength of the dollar until now is primarily based on the superior efficiency and liquidity of US dollar financial markets that long before the European and Asian markets could develop. They provide narrow bid-ask spreads, the ability to buy or sell larger amounts showing no price effects, a rich array of instruments and deep repurchase markets. To assess the competitiveness of different financial markets Alogouskoufis, Portes, and Rey (1997, p. 27) compare bid-ask spreads of benchmark government bonds (10-years to maturity). They conclude that transaction costs between the US and European markets differ by a factor of at least two in favour of the US. Another helpful indicator to evaluate the liquidity of financial markets is the ratio of turnover versus the amount of bonds outstanding traded on secondary markets. On US government bond markets in 1995 this ratio (14.0) is significantly higher than the equivalent ratios for Europe (9.9) and Japan (6.2).

Similarly, as soon as the focus shifts to private equity and corporate bond markets an unambiguous story is told. Here US markets show up to be impressively ahead in every respect. The volume of issuance of commercial papers and daily trade volumes of stocks listed at the NYSE are several times higher than in the euro area. A good example to illustrate the international standing of US dollar financial markets is the auction of UMTS licenses in Germany in August 2000. ${ }^{9}$ All companies trying to obtain one of the few "third generation" licenses offered by the government were soon faced with a rapidly rising need for funds they had to pay in euro immediately after the auction. With the total amount summing up to about 50 billion euros some of the companies announced to finance a part of their bill by issuing corporate bonds. On account of only moderately developed euro corporate bond markets they, however, had to decide to issue the major fraction of the bonds in dollar and exchange them thereafter for euro. Thus, only US dollar markets could offer the depth and breadth necessary to avoid price distortions and, hence, continuously rising capital costs. To sum up, the US dollar financial markets provide a unique degree of cost efficiency and liquidity attractive to both investors and issuers worldwide.

\section{Risk factors and the diminishing dominance of the US dollar}

The results reached so far stressed size factors like real activity (GDP, trade) and financial liquidity (inseparably connected with the transaction cost argument) as economic determinants for the international role of a currency. However, a convincing financial market perspective has to be complemented by risk factors that mainly comprise monetary stability, financial market volatility,

\footnotetext{
${ }^{9}$ See Frankfurter Allgemeine Zeitung, August 14, 2000.
} 
and cross-country asset correlations. ${ }^{10}$ International investors, be they central banks or private agents, are seeking to reduce risk by diversifying their portfolios. In a world of imperfectly correlated interest rates and equity returns the rationale of portfolio diversification smoothens the tendency of one currency to become the single international currency. Though transaction costs might be lowest when investing and financing concentrates on only one currency, investors and borrowers strive for optimising the structure of their portfolios with respect to risk-return considerations. Via this risk effect the centripetal forces of dollar liquidity are countered to some extent. Standard portfolio models of capital market theory compute an extensive degree of diversification relating to international portfolios. In reality, however, a strong home-bias "puzzle" has to be resolved (i.e. the unexpected empirical evidence that international, cross-border diversification remains below optimal levels). ${ }^{11}$

Another reason potentially limiting the dominance of the US dollar relates to the stability in monetary conditions. At the beginning of the eighties a severe economic crisis accompanied by historically high rates of expected inflation in the US diminished the attractiveness of the dollar as an international investment currency. At this time it was on the edge of not fulfilling the store of value function any more. Comparably low inflation rates in Germany associated with expectations of a further appreciation of the Deutsche mark were the result of the stability orientation and the unique reputation of the Deutsche Bundesbank. The mark became a 'save heaven' currency for investors to reduce their dependency on the US dollar. To a lesser extent the same applied to the yen. As a consequence, capital inflows enhanced the liquidity on German bond markets and finally led to spill over effects on German financial markets. In order to cope with the enormous demand for assets denominated in Deutsche mark new financial instruments and services were introduced to the markets. Such measures brought a rise in efficiency on financial markets making the Deutsche mark an even more attractive international investment currency. Within a few years the mark adopted the role of a junior international currency ranging far ahead of the yen and other currencies though still well behind the dollar.

Due to reduced needs for intervention and a rising exchange rate volatility after the break down of the Bretton Woods system changes in central bank's reserve management occurred, too. Parts of their foreign reserve portfolios were shifted away from US dollar assets and gold towards other foreign exchange reserves. European central banks linked their monetary policies to that of the Deutsche Bundesbank. In that way the (unofficial) role of the anchor currency of the European Monetary System (EMS) accrued to the Deutsche mark simultaneously fostering its role as the second international currency. Particularly, the dollar's presence as a vehicle currency intermediating between European currencies diminished for the benefit of the Deutsche mark.

In this section it has been pointed out that the US dollar serves as the by far most important international currency primarily because of the efficiency and liquidity of US dollar financial markets. The prevailing regime will most probably hold at least as long as European and other markets cannot fully compete in this respect. This is all the more important the less size differences in the real sector matter. Particularly with reference to a possible catching up of the euro with the dollar, economists like Portes and Rey (1998), Eichengreen (2000) and Wyplosz (1999) formed a financial market perspective or adopted it. When analysing transaction costs on financial markets, Wyplosz puts his view as follows: "Of all characteristics of an international currency, the

\footnotetext{
${ }^{10}$ See Detken and Hartmann (2000).

${ }^{11}$ See Tesar and Werner (1995) for a discussion and Danthine, Giavazzi, and von Thadden (2000) for actual numbers concerning the home-bias puzzle.
} 
existence of wide and deep markets with low transaction costs seems to be the most crucial." (Wyplosz, 1999, p. 95). ${ }^{12}$ To evaluate the potentials of the only serious aspirants, the euro and the yen, to challenge the position of the dollar the effects of European monetary and financial integration and the prospects of the yen should be examined.

\section{Catching up: The euro's impact via European financial market integration}

Most international economists see the launch of the euro in 1999 as one of the most important events in the Post World War II international monetary and financial system besides the creation of the Bretton Woods System and its collapse in the early seventies. ${ }^{13}$ Twelve members of the European Union (Greece joined at the beginning of 2001) abolished their national currencies and delegated their monetary policy to a supranational and independent authority, the European Central Bank (ECB). Although the circulation of euro notes and coins will start only at the beginning of 2002 the new currency has completely replaced the legacy currencies from the outset.

In this section we deal with the question of to what extent the euro has already triggered European financial markets to overcome their historically generated segmentation on the road to truly unified markets. Although mainly confined to intra-European markets this investigation is undertaken against the background of the future international potential of the euro. Evidence for the first two years of the euro regarding key segments of European financial markets (i.e. money, bond, equity markets) lead observers to speak of a "revolution in European finance" (Eichengreen, 2000, p. 356). In the following the available evidence is reviewed.

Before going into details three caveats should be pointed out. First, by analysing the forces at work that develop and integrate European financial markets problems arise how to distinguish between effects purely resulting from the introduction of the euro and those which would have happened regardless of its launch. Nonetheless, one can agree to the view that the new currency works at least as a catalyst for European financial market developments with the "precise role of EMU difficult to quantify." (Danthine et. al., 2000, p. 3). Second, due to the East Asian financial crisis starting in 1997, the Russian sovereign default, and the crash of the Long Term Capital Management hedge fund (LTCM) both coming up during autumn 1998 international investors returned to a 'save haven' strategy focussing mainly on dollar investments. In contrast, international and European borrowers issued large volumes of euro-denominated bonds in the first year after the introduction of the euro. However, strong one-off effects played their part, since large companies intended to establish a benchmark position within the deeply underdeveloped European corporate bond market. ${ }^{14}$ Third, the long lasting slump of the euro against the dollar (and the yen) that after a depreciation of about $35 \%$ since its introduction came to an end only in October 2000. This unfavourable development most probably impeded the attraction of funds to European financial markets. Though, Danthine et al. (2000, p. 4), in attesting European financial markets an "excellent performance...despite the depreciation" play down the importance of this issue. Most recent BIS data on international debt securities markets show that the dollar recaptured its leading position on international bond markets: While throughout 1999 the euro had a slightly higher share of international debt issues (571 vs. 545 billions of US dollars) the dollar

\footnotetext{
${ }^{12}$ Further fundamental work with respect to the euro's impact on European and international financial markets has been done by McCauley (1997), McCauley and White (1997) and Prati and Schinasi (1997).

${ }^{13}$ See Bergsten (1997, p. 17).

${ }^{14}$ See Bayle et al. (2000, p. 42ff.).
} 
clearly surpassed the euro by $29 \%$ during the first three quarters of 2000 (BIS, 2000b, p. 24). Bearing in mind these caveats a careful interpretation of the prevailing evidence will be tried in the following.

\section{Money markets}

European money markets rapidly expanded and established a high degree of integration subsequent to the adoption of the euro and the concurrent implementation of a single monetary policy. Already the run-up to EMU showed a considerable convergence of money market rates ("convergence trading"). Quite important though, for the two most significant segments of the euro money markets - the secured (repo) and the unsecured segment - a distinction has to be made with reference to their individual integration progress. ${ }^{15}$

While the repo market demands collateralization in addition to the exchange of short-term liquidity the unsecured interbank market just involves the latter. National differences in procedures used across the numerous securities trading platforms, clearing houses, and securities settlement systems are the most impeding factors (OECD, 2000, p. 64) for a single repo market. By contrast, unsecured money markets solely require a payment system (a cash "leg") but no additional securities "leg" (ECB, 2000, p. 53). ${ }^{16}$ Two main sources are held responsible for the speed and the high degree of integration with respect to this segment. First, after minor initial operational problems TARGET, the major settlement system for large-value payments in the euro area functions smoothly and plays a key role in facilitating the redistribution of liquidity across the euro area. ${ }^{17}$ The domestic share of money market activity of the largest market participants therefore diminished from 54\% in 1998 to $40 \%$ in 1999 (ECB, 2000, p. 18). In addition, via this trouble-free cross-border payment facility price differentials in the prevailing national segments of the money market throughout the euro area have been offset by arbitrage operations. Second, two benchmark indices, EONIA (euro overnight index average) and EURIBOR (euro area interbank offered rate), have been placed in the field of the euro area money market. Immediately after the start of the euro they were "broadly accepted by all market participants" (ECB, 2000, p. 24) and for that reason created a single money market reference yield curve acting also as the backbone for the booming derivative market activities. In this money market "network" derivative markets generate a positive feed back into the spot money markets. Turnover in both segments boosted, a self-reinforcing process of liquidity calling liquidity emerged.

An appropriate indicator for this development can be found in the form of a decline in money market transaction costs. For the three months segment one can observe continuously dropping bid-ask spreads of annually 10\% since 1996. A comparison with the corresponding US segment shows approximately identical transaction costs of about 9 basis points in $1999 .^{18}$

With regard to the unsecured and the swap segments, the TARGET system in conjunction with the rapidly established euro area indices enabled market participants to play in a melted single market. Taken together, integration and standardization of all segments of European money markets are not yet complete. Especially in the case of the repo market further evolutions can be expected in order to get closer to US dimensions.

\footnotetext{
${ }^{15}$ The secured and unsecured segments show a combined share of 77\% of euro money market activity in 1999 (ECB, 2000, p.15).

${ }^{16}$ These infrastructural problems on European securities markets are taken up below.

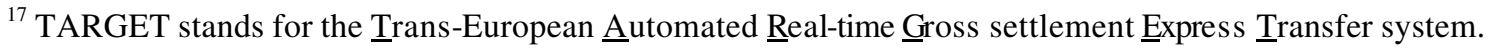

${ }^{18}$ See BIS (2000, p. 124).
} 


\section{Bond Markets}

Extensive as well as unexpected changes came about on European bond markets, especially concerning the corporate bond sector. The euro changeover period was characterised by the smooth redenomination of government bonds formerly denominated in the euro legacy currencies into euro-denominated bonds. New debt since then has been exclusively issued in euro. Bonds also have been reconventioned. ${ }^{19}$ The fundamental element of change was the removal of currency risk. Thus an equal risk base emerged throughout the euro area. Both investors and borrowers had to attune to a broader set of feasible transactions thereby increasing demand- and supplysided potentials of EMU bond markets. ${ }^{20}$ Former constraints to invest on a cross-border scale, such as currency matching rules applying to insurance companies and pension funds disappeared. Previous to EMU, life insurance companies in Germany, the Netherlands, Spain, and Italy, for instance, were obliged to invest at least $80 \%$ of their total assets in their respective home currency. Moreover, commercial bank's requirements for raising central bank credit through repurchase agreements were without exception based on national collateral. When these restrictions faded away the focus of market participants gradually could shift from currency risk to other risk characteristics such as credit and liquidity risk. A new need for portfolio diversification resulted from this shift entailing the expectation of the euro area home-country bias in investing and financing to be reduced. This prediction definitely holds not only for European bond markets but also for European asset markets in general.

\section{Government bond markets}

When analysing government bond markets in the euro area the main item is the convergence of yield differentials across participating economies. Is it a realistic appraisal to expect yield differentials to peter out completely and thus a formation of a truly integrated market that treats e.g. Spanish and French bonds as perfect substitutes? To tackle this question one has to examine the major risk components that are the reason for spreads in bond markets: fundamental (default or credit) risk, currency risk, and liquidity risk. Previous to monetary union existing spreads mainly reflected the currency risk component of bonds issued by countries that have been more inflationprone than stability-oriented Germany. Once the irrevocable fixing of the euro area exchange rates was announced in May 1998 currency risk vanished and therefore the decline in yield spreads already observable prior to that announcement accelerated to amounts below 40 basis points for bonds of two- to ten-year maturity. ${ }^{21}$ In the precedent years spreads between 200 and 400 basis points had been common. However, it stands out that many issuing governments even now have to pay a premium compared to German issues, especially concerning the German 10-year bond representing the key segment of the yield curve. Now that the bulk of issuance is denominated in euro other factors must explain interest rate spreads in the euro area.

At first sight one might suppose fundamental risk to be responsible for remaining spreads, primarily because the Maastricht Treaty by means of the "no-bail-out" clause (Article 104b) prohibits any shared liability for debt of single EMU member countries. Yet, technical and liquidity reasons rather than the risk of default by a member state have been identified by market

\footnotetext{
${ }^{19}$ The reconventioning encompasses, for instance, standardized rules concerning the pay and calculation of interest thereby turning these bonds into more comparable and substitutable assets. Most private issuers adapted to these rules.

${ }^{20}$ See Danthine et al. (2000, p. 17ff.).

${ }^{21}$ See BIS (2000, p. 126).
} 
observers. ${ }^{22}$ In consequence, liquidity risk remains as the key factor in determining the prevailing yield spreads even though differences in credit risk are by no means abolished.

An outstanding element of European financial market's new landscape that explains the liquidity risk component is the enhanced competition of public debt issuers. Each government attempts to minimise their debt servicing costs by attracting the demand side of the market. National debt management agencies are forced to acknowledge investor's surge for portfolio diversification and therefore are afraid of losing their traditional "home base". Moreover, the current low-yield environment together with the absence of exchange rate risk forced European investors to diversify not only geographically but also into the corporate debt segment that offers higher riskreturn combinations. These competitive circumstances forced national Treasuries to start a "race to the benchmark yield curve" (Danthine et al., 2000, p. 19) providing a considerable "built-in liquidity" advantage for large sovereign issuers like Germany, France, and Italy. Especially the smaller issuers (e.g. Ireland and the Netherlands) currently undertake benchmark policies to foster certain maturities or innovative products (niches) since their total amount of government debt is too small to ensure sufficient liquidity through the whole yield curve. However, big volumes of outstanding and newly issued debt alone cannot account for a benchmark status. Issuance has to be supplemented by specific issuance procedures, market transparency as well as secondary and derivative market liquidity. For instance, within the two- and the ten-year sector German bonds are the benchmark in the latter case mutually reinforced by the turnover of the actually incontestable Bund future contract at Eurex, Frankfurt's Swiss-German derivatives exchange. France, conversely, sets the benchmark in the intermediate five to seven-year range and for maturities of over ten years (ECB, 2000, p. 39).

On the one hand the observable rivalry and the diverging issuance strategies give way for innovative and transparent market behaviour. On the other hand idiosyncratic national debt management cannot exploit the potential economies of scale only a unified market structure could offer and therefore will remain more costly than US Treasury's debt management. While the US Treasury serves as a centre of gravity a central euro issuer is missing. Furthermore, there are drawbacks for other financial market segments. A well defined government ("risk-free") yield curve is lacking so that the pricing of corporate bonds misses a generally accepted floor. Also, the market for secured short-term deposits (repo market) suffers from the deficient harmonization of bond market conventions.

To summarize, the competition for liquidity and differences in credit risk bear the consequence of a non-unique government yield curve. Furthermore, a truly unified market in this field is hardly to be expected in the next future. As the BIS puts it in their last annual report: "Any argument based on the economic benefits of greater coordination has to be carefully weighed against the further erosion of national independence." (BIS, 2000, p. 127). Additionally, according to a recent report prepared for the European Commission by the Giovannini Group (2000), "co-ordination involving a joint or single debt instrument was not regarded as a practical option for the euro area as a whole." This allows for a preliminary conclusion to be drawn on the competition between the dollar and the euro concerning their international roles - the disadvantage for the euro is unambiguously evident.

\section{Corporate bond markets}

Right with the launch of the euro huge changes evolved for the previously underdeveloped European corporate bond markets and put them into a "new dimension" (ECB, 2000, p. 47). The first three quarters of 1999 revealed a stunning increase in euro-denominated corporate bond

${ }^{22}$ See BIS (2000) and Danthine et al. (2000) for details. 
issues (i.e. global issuance) by $390 \%$ compared to $1998 .^{23}$ The doubling of the average size of individual corporate bond issues also documents the soared liquidity. Along with this increase of market depth the breadth of the market enhanced, too. Baa-rated bond issuance boosted by $529 \%$, however starting from a very low level, while bonds rated AA or A still rose by 55\% respective $122 \%$ (ECB 2000, p. 39). Consequently, average credit ratings of companies that tap the bond market have fallen - a clear move towards US American conditions.

Yet, one should bear in mind two important facts to qualify these figures. First, European private non-corporate debt issuers (i.e. banks and other financial intermediaries) in 1999 still outperformed corporate issuers by a factor bigger than 4 (ECB, 2000, chart 16). Second, the magnitude of the European corporate bond market - measured by market value of outstanding issues - still is merely one fifth of its US counterpart (ECB, 2000, p. 48). Notwithstanding, a further expansion of the European corporate bond markets is to be expected. Gros and Lannoo (2000) present several arguments contributing to this favourable outlook:

- A less growing government debt market due to the Stability and Growth Pact,

- historically low yields of government debt,

- no constraints by formerly (bad) credit ratings of the issuers country ${ }^{24}$, and

- lower issuing costs resulting from stronger competition between market intermediaries in a more liquid euro-market.

Moreover, the merger and acquisition boom in many sectors, especially in the telecommunication sector, amplifies the financing needs for companies. Finally, demand-side effects also matter. Investors have more capital at their disposal, for instance due to gradually supplementing the payas-you-go pension systems by a capital pillar in Germany and elsewhere. Even more important, as has been mentioned above, investors show a readiness to diversify on a geographical (crossborder) scale as well as into riskier asset classes.

To sum up, contrary to the sovereign debt market, European corporate bond markets were largely underdeveloped prior to EMU. The evidence mentioned reveals an astonishing boom that appears to have overcome the critical mass effect. "A broader used currency and more liquid capital market could attract more issues than the sum of the component currencies before, as seems to be the case so far in the first months of EMU." (Gros and Lannoo, 2000, p. 44). Nonetheless, even considering all these factors, it might take a decade for the corporate capital markets in Europe to be comparable in size with its US equivalent. ${ }^{25}$

\section{Equity markets and securities market infrastructure}

The integration of European equity markets reveals an ambivalent picture. The pure magnitude, measured e.g. as turnover on primary and secondary markets in 1999, has grown rapidly along various dimensions including the successful implementation of high-tech sectors like the German Neuer Markt. ${ }^{26}$ A more efficient organization of the market structure and initiatives to integrate European equity markets, however, turned out to be less successful, as the failed merger of the London Stock Exchange and Deutsche Börse has illustrated. The latter problem, though, applies to the European securities markets in general because the trading, clearing, and settlement

\footnotetext{
${ }^{23}$ The exact figures are $€ 117$ vs. $€ 30$ billion. See Eichengreen (2000, p. 363).

${ }^{24}$ Solvent companies may have a better rating than their central government.

${ }^{25}$ Other segments of European bond markets, e.g. the asset-backed securities market and the bond-related derivatives market, grew strongly, too. Especially, the German "Pfandbriefe" market established a high acceptance on a European scale; see ECB (2000, p. 48f).

${ }^{26}$ Numbers for 1999 show a $66 \%$ increase in euro equity issues and a $42 \%$ increase in European equity trading volume. See Danthine et al. (2000, footnote 36).
} 
infrastructure still contains huge efficiency potentials.

Against this background, it has to be asked whether the euro can promote the geographical diversification away from nationally oriented equity portfolios. Prior to EMU, it was generally expected that structural changes in equity flows would decrease the enormous equity home-bias. According to that logic, national impacts on share prices should diminish since now it is less probable that shocks emanate from national macroeconomic policies. Monetary policy is conducted by the ECB, fiscal policy is restricted due to the Stability and Growth Pact and currency risk has been eliminated. Hence, (macroeconomic) country risk would converge and thus the widespread strategy of managing a portfolio country-by-country should be abandoned in favour of a euro area-wide sector-by-sector view. In fact, to some extent this behavioural switch already materialized as indicated by the appearance of pan-European or euro area stock market indices (e.g. Stoxx-50 and Euro-Stoxx 50). The available evidence relating to a shrinking homebias, however, is still rather unconvincing. Danthine et al. (2000) in their thorough analysis present figures that support tendencies of a slow portfolio rebalancing across euro area sectors. At the same time, however, the Bank for International Settlement claims that "prices continue to be driven principally by local investors with a considerable geographical portfolio bias." (BIS, 2000, 133).

Besides behavioural sluggishness, the basic issue at stake is the problem of the complex European trading, clearing, and settlement infrastructure. ${ }^{27}$ Notwithstanding the aforementioned mixed evidence regarding first steps towards portfolio rebalancing, a broad consensus exists with respect to the still massive (i.e. expensive) barriers to cross-border portfolio investment in the euro area. This fragmentation matters since it limits further integration and portfolio diversification and thereby impedes the development of a unified European capital market. Transaction costs resulting from inefficient structures impose a type of tax on trading and by that restrain investors from achieving optimum portfolios. $^{28}$

The case of European stock exchanges striving for alliances or cooperation serves to illustrate this difficulty. Overly optimistic, in June 2000 the Bank of England expressed: "The proposed merger between the London Stock Exchange (LSE) and Deutsche Börse [...] is a key step in the consolidation of the European exchange infrastructure, and likely to encourage further consolidation of clearing and settlement services." (Bank of England, 2000, p. 7). Yet, due to several unsettled problems and finally induced by fears that the hostile bid of OM, a Swedish technology company, could be successful the LSE withdrew from their plan to fuse the two biggest European exchanges into iX (International Exchanges) in September 2000. Meanwhile, another alliance has been successfully founded in September 2000: Euronext, the merged Paris, Brussels, and Amsterdam exchange, is going to start business in summer 2001. These events reflect the competitive pressures traditional exchanges are exposed to. They are not only alarmed about (un)friendly takeover strategies by established exchanges but also feel challenged by newly emerging electronic platforms like virt-X or Jiway. ${ }^{29}$

Beyond the missing integration in securities trading, in particular segmented European clearing and settlement systems are regarded as being too expensive compared to US structures. Standardized trading of securities requires not only a trading platform in the form of electronic or traditional exchanges, but also the settlement of cash and securities through clearing houses and securities

\footnotetext{
${ }^{27}$ For a detailed description of the different components of the European financial infrastructure see ECB (2000, p. 53ff).

${ }^{28}$ See ECB (2000, p. 41) and Gros and Lannoo (2000, p. 67ff).

${ }^{29}$ See The Economist (2000).
} 
settlement systems. Previous to EMU, these systems were organized nationally. Moreover, relating to monetary and fiscal relations, the pre-EMU legal environment was mainly built upon national peculiarities. Market and central bank practises together with tax and accounting regimes differed to a large extent. The bare introduction of the euro hardly changed this setting. Although the European Commission issued directives relating directly to legal issues (e.g. Investment Services Directive, Capital Adequacy Directive and Settlement Finality Directive), a lot of differences still exist. Particularly, little progress has been made concerning such key areas as taxing and accounting. ${ }^{30}$

The overall picture shows that the structure of European stock exchanges is still shattered with no single pan-European exchange in sight. The same holds for the complete range of European securities infrastructure (trading, clearing, and settling). Economies of scale would call for merging the multiple clearing houses and securities settlement systems to one central agency because "settlement is the most expensive part of cross-border trading, and can cost up to ten times as much as in America." (The Economist, 2000).

The main results drawn so far in section four may best be summarized by the following statement: "Even after the introduction of the euro capital markets will retain a strong national flavour. 1999 will thus see the start of a process of unification, rather than its completion." (Gros, 1998, p. 26f.). With hindsight, this forecast for the most part has been corroborated by the above presentation of actual developments. However, it should be kept in mind that different segments of European financial markets differ with respect to their pace of integration.

\section{European monetary policy}

Besides financial market integration a sound design of European monetary policy is an indispensable issue when discussing the future international role of the euro. A crucial factor for a good performance of an international currency is whether monetary policy will be dedicated to price stability and therefore will gain the confidence of international investors and borrowers. With respect to the euro area the independence of the European Central Bank (ECB), its obligation to first and foremost strive for price stability and the prohibition of financing public budget deficits both fixed by the Maastricht Treaty are necessary conditions in this respect. Equally important is the validity of the Stability and Growth Pact that shall ensure a permanent upper limitation of public debt and deficits and even provides punishment for diverging. Only a sustained acceptance of this clear assignment will support an increasing international role for the euro.

However, a political void exists when analysing the responsibility for exchange rate policy. Only the European Council of Ministers (and not the ECB) is authorized to initiate international agreements on fixed exchange rates and target zones for exchange rates (Maastricht Treaty: art. 109) thus potentially undermining efforts taken by the ECB to defend price level stability. Moreover, the reputation of the ECB hinges on a convincing explanation of its monetary policy strategy to the actors on international financial markets and the general public. Deficits in this field together with debates about an appropriate degree of transparency of the ECB's policy decisions arose during the first two years of EMU. ${ }^{31}$

\section{Inertia}

The analysis carried out so far suggests that the euro could catch up with the dollar in the long run.

\footnotetext{
${ }^{30}$ See ECB (2000, 57ff).

${ }^{31}$ Problems in the broader field of macroeconomic policy are not to be discussed in this paper. One should, however, bear in mind that structural reforms on labour markets and the restructuring of existing pay-asyou-go pension schemes should be of first priority in most continental European countries.
} 
But forecasts about the speed of adjustment are very difficult to obtain and are likely to produce only poor results. Empirical knowledge tells us that economic agents are risk-averse and only prudently adjust their traditional behaviour to structural changes. Inertia is a reasonable assumption in the light of uncertainty. Though the competition between the US dollar and the euro is going to be finally decided on international financial markets, inertia in the behaviour of economic agents supports the argumentation that the catching up of the euro could be quite slow even though the majority of economic indicators might point into another direction. It is important to note that no sufficient condition exists to claim for a world currency status. Even in the situation of equal transaction costs, though, a switch from one currency to another could be delayed because uncertainty works towards sluggish behaviour. History dependency therefore matters more than automatism. One clearly has to distinguish between laying the institutional, economic, and political foundations on the one hand and convincing market participants to effectively change their behaviour on the other.

Consequently, it seems to be almost impossible to make an assessment for a plausible timeframe as long as it remains uncertain whether a shift will occur at all. Though, Portes still holds on to link the possible international role of the euro directly to progresses made on European financial markets: "The time frame of the analysis [the euro drawing up with the dollar] is that of the integration of euro-area financial markets - say five to ten years" (Portes, 2000, p. 7). This assessment should be altered insofar as it characterizes a realistic timeframe for attaining the quantifiable preconditions for a leading international currency. More prudently, we join the opinion expressed by Wyplosz: "Finally, we are looking at a very slow process. The virtuous cycle of declining costs and growing market size is unlikely to unfold fast. The time-scale is measured in decades not in months." (Wyplosz, 1999, pp. 88, 95).

\section{The position of the yen: Insufficient political backing}

After having evaluated the prospects of the euro as an international currency a few remarks should sketch the dismal prospects of the yen to join the euro in potentially competing with the dollar. Initially and most crucial, political conditions in Japan and East Asia are absolutely different from those prevailing in the European Union. Critics of the process of European integration argue that a lack of political unity in Europe works against a sustainable EMU. ${ }^{32}$ If one attaches importance to this reasoning there is practically no way for Japan to further promote the role of the yen because of heavy political obstacles that might arise when trying to form an East-Asian economic bloc comparable to the EU in this region. Due to historical burdens stemming from Japans occupations in other Asian countries in the first half of the $20^{\text {th }}$ century cooperation between Japan, South East Asian countries, and perhaps China to push a pan-Asian currency (presumably the yen) must be regarded as exceptionally unlikely. Against this background it is all the more astonishing that in Japan the internationalization of the yen is announced to be an explicit political target. The latter is indicated by the appointment of a "Study Group for the Promotion of the Internationalization of the Yen" in $1999 .{ }^{33}$

On purely economic grounds and commensurate with its clout in terms of GDP and technological sophistication, Japan, the second-largest world economy, would have to perform the role of an obvious regional leader. Though, an "unresolved issue of leadership" exists, as Grenville, the Deputy Governor of the Reserve Bank of Australia, states when considering the possibilities of

\footnotetext{
${ }^{32}$ Most prominent among them is Feldstein (2000b).

${ }^{33}$ See Japanese Ministry of Finance (2000).
} 
financial regional arrangements in East-Asia. For this reason the yen hardly has a chance to catch up with the dollar or the euro. A thorough analysis of Japanese respective Asian financial markets therefore is not useful in broadening the understanding. ${ }^{34}$

The figures presented in section 3 (tables 2-4) as well as recent economic conditions in Japan and South East Asia substantiate our guarded view to the yen's international prospects. It is worth to reconsider the 0.6 value for the yen's coefficient of internationalization (table 3 ). This means that in 1992 the yen was used to denominate trade by far less than the value of combined Japanese imports and exports. The corresponding numbers for the US dollar and the Deutsche mark are 3.6 and 1.4, respectively. This implies that concerning the patterns of invoicing the yen is significantly underrepresented compared to Japan's potency in world trade. Moreover, relatively intense US trade with East Asia together with the tendency of South East Asian countries to peg their currency to the dollar even after the currency crisis in 1997/98 prevents the yen from being the natural regional currency even in its "own" area. Likewise, figures on economic size, openness (table 2), and turnover on foreign exchange markets (table 4) strongly underscore the weak position of the yen if compared to the dollar and the euro (resp. its predecessor currencies).

Additionally, deteriorations regarding the region's economic performance in recent years should be noted. Japan and South East Asia still suffer from the consequences subsequent to the financial and economic crisis at the end of the nineties. Furthermore, Japan so far did not overcome all problems caused by the burst of the bubble economy in the early nineties. The growing indebtedness of the Japanese government (130\% of GDP in 2000) due to extensive public spending is commonly seen as another striking problem. On this account, yen-denominated Japanese government bonds have been downgraded in September 2000 by Moody's. ${ }^{35}$ Overall, in the foreseeable future the yen most probably cannot establish functions of an international currency comparable to the dollar or the euro. Even a regional dominance of the yen in East Asia must not be taken for granted.

\section{Outlook for the future international currency regime}

The present currency regime privileges the US absorbing most extra benefits since they are the issuer of the leading international currency. Today the euro can be considered the only currency to have the potential of threatening the dominance of the dollar. Thinking ahead to what the international currency system could look like in the future it is useful to briefly reconsider the most prominent characteristics making a currency to be preferred on a world-wide level:

1. real activity: size of output (internal market) and trade (share in world trade),

2. liquidity: size and sophistication of financial markets,

3. risk factors: monetary and exchange rate stability, stability of economic policy, and

4. inertia (history dependency and institutional settlements).

While real activity in terms of GDP and share in world trade does not clearly privilege any of the economic blocs in question an analysis of financial liquidity seems to be a more promising field of study. It has been shown in more detail that Europe is on the wake of moving towards highly developed financial markets whereas Japan is bounded to its narrow domestic markets with no political perspectives to establish a unified Asian market. Should the UK join EMU in the near future the European integration could ultimately accelerate. The prospects for providing financial

\footnotetext{
${ }^{34} \mathrm{~A}$ thorough and refined analysis of the yen as an international currency has been worked out by Strube (2001).

${ }^{35}$ See Financial Times (2000).
} 
liquidity in Europe are fostered by the irrevocable process of political integration. At the end, Europe might emerge as a political unity comparable to the US with the ability to guarantee a degree of stability necessary to satisfy the demands of market participants. In this respect, Japan has to face clear political disadvantages that will finally obstruct all efforts undertaken to promote the yen as an international currency. Despite great opportunities for the euro to draw level with the dollar in terms of size and sophistication of financial markets as well as with political stability inertia in combination with switching costs are likely to retard a catching up of the euro for decades. We suppose that the previous historical experience of only gradually changing supremacy of international currencies still applies. However, it must not be excluded that unexpected shocks may completely change the scenario outlined above. 


\section{References}

Bank for International Settlement (2000a): $70^{\text {th }}$ Annual Report, Basel.

Bank for International Settlement (2000b): International Banking and Financial market Developments, November 2000, Basel.

Bank for International Settlement (1999): Central Bank Survey of Foreign Exchange and Derivatives Market Activity 1998, Basel.

Bank of England (2000): Practical Issues Arising from the Euro, June 2000.

Bayle, M., Santillán, J., and Thygesen, C. (2000): The impact of the euro on money and bond markets, ECB Occasional Paper 1.

Berger, A. N., DeYoung, R., and Udell, G. F. (2000): Efficiency barriers to the consolidation of the European financial services industry, European Financial Management 6.

Bergsten, C. F. (1997): The impact of the euro on exchange rates and international policy cooperation, in: Krueger, T. H., Masson, P. R., and Turtelboom, B. G. (eds.), EMU and the International Monetary System, IMF, Washington, DC.

Black, F., and Scholes, M. (1973): The pricing of options and corporate liabilities, Journal of Political Economy 81, 637-659.

Cohen, B. (1998), The Geography of Money, Cornell: Cornell University Press.

Danthine, J.-P., Giavazzi, F., and von Thadden, E.-L. (2000): European financial markets after EMU: A first assessment, paper presented at the Bundesbank/BIS conference on "Recent Developments in Financial Systems and their Challenges for Economic Policy: a European Perspective", Frankfurt 28/29 September.

De Grauwe, P. (2000): The euro dollar exchange rate in search of fundamentals, mimeo.

Detken, C., and Hartmann, P. (2000): The euro and international capital markets, ECB Working Paper 19.

Economist, The (2000): European stock exchanges - Two into three, July 22.

Eichengreen, B. (2000): The euro one year on, Journal of Policy Modeling, 22(3), 355-368.

European Central Bank (2000): The external trade of the euro area economy: Stylised facts and recent trends, ECB Monthly Bulletin August 2000.

European Central Bank (1999): The international role of the euro, ECB Monthly Bulletin August 1999.

European Commission (2000): Report on co-ordinated issuance of public debt in the euro area. Report of the Giovannini Group, http://europa.eu.int/comm/economy_finance/ document/ euro/giovannini1100_en.htm

Emerson, M., Gros, D., Italianer, A., Pisani-Ferry, J., and Reichenbach, H.: (1991): One Market, One Money, Oxford: Oxford University Press.

Feldstein, M. (2000a): Aspects of global economic integration: Outlook for the future, NBER Working Paper 7899.

Feldstein, M. (2000b): The European Central Bank and the euro: The first year, Journal of Policy Modeling, 22(3), 345-354.

Financial Times (2000): Japan's credit rating downgraded by Moody's, September 8.

Frankfurter Allgemeine Zeitung (2000): Vor einer Flut von Telekom-Anleihen, August 14.

Grassman, S. (1973): A fundamental symmetry in international payment patterns, Journal of International Economics 3, 105-116.

Grenville, S. A. (2000): Notes on East Asian financial cooperation, speech reprinted in: BIS Review 68, 2000.

Gros, D., and Lannoo, K. (2000): The Euro Capital Market, Chichester: Wiley. 
Gros, D. (1998): EMU and Capital Markets - The Institutional Framework, Brussels.

Hartmann, P. (1998): Currency Competition and Foreign Exchange Markets: the Dollar, the Yen and the Euro, Cambridge: Cambridge University Press.

International Monetary Fund (2000): Annual Report, Washington DC.

Japanese Ministry of Finance (2000): Interim Summarization (June 30, 2000) of the Study Group for the Promotion of the Internationalization of the Yen (Provisional Translation), http://www.mof.go.jp/English/if/if025b.htm.

Kindleberger, C. P. (1973): The World in Depression, 1929-1939, Berkeley: University of California Press.

Krugman, P. (1999): The Return of Depression Economics, New York: Norton.

Krugman, P (1992): Currencies and Crisis, Cambridge: MIT Press.

Kunz, D (1995), The fall of the dollar order: The world the United States is losing, Foreign Affairs 74, 4.

McCauley, R. N. (1997): The euro and the dollar, BIS Working Paper 50.

McCauley, R. N. and White, W. R. (1997): The euro and European financial markets, BIS Working Paper 41.

Portes, R. (2000): The role of the euro in the world: Past developments and future perspectives, presented at the Bundesbank/BIS conference on "Recent Developments in Financial Systems and their Challenges for Economic Policy: a European Perspective", Frankfurt 28/29 September.

Portes, R., and Rey, H. (1998): The emergence of the euro as an international currency, Economic Policy, 26, 307-343.

Prati, A., and Schinasi, G. J. (1997): European monetary union and international capital markets: Structural implications and risks, IMF Working Paper 62.

Rey, H. (1999): International trade and currency exchange, CEPR Discussion Paper 2226.

Rogoff, K. (1998): Blessing or curse? Foreign and underground demand for euro notes, Economic Policy, Vol. 26, 263-303.

Schwartz, A. J. (2000): The rise and fall of foreign exchange market intervention, NBER Working Paper 7751.

Shapiro, C., and Varian, H. R. (1999): Information Rules: A Strategic Guide to the Network Economy, Boston, Mass., Harvard Business School Press.

Steinherr, A. (1998): Derivatives, the Wild Beast of Finance, Chichester, Wiley.

Strube, J. (2001): Der japanische Yen als internationale Währung - Voraussetzungen, funktionale Interdependenzen und Motive der Währungswahl, mimeo, Ruhr-Universität Bochum.

Summers, Lawrence H. (1999): Economic engagement: The risk of malign neglect, speech, http://www.ustreas.gov/press/releases/ps179.htm.

Tesar, L., and Werner, I. (1995): Home bias and high turnover, Journal of International Money and Finance 14, 467-492.

Wyplosz, C. (1999): An international role for the euro?, in: Dermine, J. and Hillion, P. (eds.:), European Capital Markets with a Single Currency, 76-104, Oxford: Oxford University Press. 


\section{Diskussionsbeiträge des Instituts für Europäische Wirtschaft}

Nr. 1 Peter M. Schmidhuber: Die Vertiefung des Gemeinsamen Marktes und die Bewältigung der zweiten Stufe der Wirtschafts- und Währungsunion. Bochum 1994.

Nr. 2 Dieter Schneider: Sichert das Standortsicherungsgesetz die Attraktivität Deutschlands als Wirtschaftsstandort für ausländische Unternehmen? - Eine Teilantwort anhand effektiver Grenzsteuerbelastungen für US-Direktinvestitionen in Deutschland. Bochum 1994.

Nr. 3 Wim Kösters: On the Stability Conception of the Maastricht Treaty: Interpretation and Critical Assessment. Bochum 1994.

Nr. 4 Cay Folkers: Die Kompensationsfunktion des Europäischen Haushalts - Zur ökonomischen Analyse der EU-Finanzen im Integrationsprozeß. Bochum 1994.

Nr. 5 Dieter Bender, Norbert Lamar: EWS-Bandbreitenerweiterung, Konvergenz und Währungsunion. Bochum 1995.

Nr. 6 Wim Kösters, Ansgar Belke: The Unemployment Problem in the EU: Theories and Evidence. Bochum 1995.

Nr. 7 Ansgar Belke: Testing for Unit Roots in West German an U.S. Unemployment Rates: Structural Breaks or Stochastic Trends in European Unemployment? Bochum 1996.

Nr. 8 Ansgar Belke: Maastricht - Implikationen einer zentralisierten Geld- und Währungspolitik für die Beschäftigung in Europa. Bochum 1996.

Nr. 9 Ansgar Belke: Wechselkursfixierung in einer EWU: Chance oder Risiko für die Beschäftigung in Westeuropa? Bochum 1996.

Nr. 10 Peter Hammann, Thorsten Stritzki, Cordula Tebbe: Das Key-Account-Management als Reaktion auf die Handelsentwicklung in Europa - eine empirische Untersuchung am Beispiel der Kosmetikindustrie. Bochum 1996.

Nr. 11 Ansgar Belke: Zur Politischen Ökonomie der Westeuropäischen Arbeitslosigkeit: Mancur Olson versus Insider-Outsider-Theorie. Bochum 1996.

Nr. 12 Berthold Busch, Karl Lichtblau, Claus Schnabel: Kohäsionspolitik, Konvergenz und Arbeitslosigkeit in der Europäischen Union: Eine empirische Analyse mit Regionaldaten. Bochum 1997. 
Nr. 13 Ansgar Belke, Daniel Gros: Evidence on the Costs of Intra-European Exchange Rate Variability. Bochum 1997.

Nr. 14 Ingo Pies: Globalisierung und Demokratie: Chancen und Risiken aus ökonomischer Sicht. Bochum 1997.

Nr. 15 Ansgar Belke: Setting Euro Conversion Rates: A Comment on the de Grauwe-Proposals. Bochum 1997.

Nr. 16 Ansgar Belke, Daniel Gros: Estimating the Costs and Benefits of EMU: The Impact of External Shocks on Labour Markets. Bochum 1997.

Nr. 17 Dieter Bender, Norbert Lamar: European Financial Integration and EMU Expectations. Bochum 1997.

Nr. 18 Ansgar Belke: EWU, Geldpolitik und Reform der Europäischen Arbeitsmärkte. Bochum 1997.

Nr. 19 Ansgar Belke, Daniel Gros: Modelling the „Option Value of Waiting“: More Evidence on the Costs of Intra-European Exchange Rate Volatility. Bochum 1998.

Nr. 20 Wim Kösters: Europäische Integration: Wirtschaftspolitischer Autonomieverlust durch Supranationalisierung politischer Entscheidungen. Bochum 1998.

Nr. 21 Ingo Pies: Liberalismus und Normativität: Zur Konzeptualisierung ökonomischer Orientierungsleistungen für demokratische Politikdiskurse. Bochum 1998.

Nr. 22 Ansgar Belke, Matthias Göcke: A Simple Model of Hysteresis in Employment under Exchange Rate Uncertainty. Bochum 1998.

Nr.23 Ansgar Belke, Matthias Göcke: Micro- and Macro-Hysteresis in Employment under Exchange Rate Uncertainty. Bochum 1998.

Nr. 24 Ansgar Belke, Daniel Gros: Asymmetric Shocks and EMU: On a Stability Fund. Bochum 1998.

Nr. 25 Cay Folkers: Neue Maßstäbe in der Europäischen Union: Grenzen für Staatsverschuldung und Staatsquote durch den Maastrichter Vertrag und seine Ergänzungen. Bochum 1999. 
Nr. 26 Un-Chan Chung: East Asian Economic Crisis - What is and What Ought to be Done: The Case of Korea. Bochum 1999.

Nr. 27 Ansgar Belke: Beschäftigungswirkungen institutioneller Arbeitsmarktunterschiede und währungspolitische Arrangements bei stufenweiser EU-Osterweiterung. Bochum 1999.

Nr. 28 Ansgar Belke: Towards a Balanced Policy Mix under EMU: Co-ordination of Macroeconomic Policies and ,Economic Government'? Bochum 1999.

Nr. 29 Gerhard Wegner: Zur Funktionsfähigkeit des institutionellen Wettbewerbs - Ein Beitrag zur Theorie des Systemwettbewerbs. Bochum 2000.

Nr. 30 Ansgar Belke, Daniel Gros: Designing the EU-US Atlantic Monetary Relations: The Impact of Exchange Rate Variability on Labor Markets on Both Sides of the Atlantic. Bochum 2000 .

Nr. 31 Rainer Beckmann, Martin Hebler, Wim Kösters, Markus Neimke: Theoretische Konzepte zum Europäischen Integrationsprozeß: Ein aktueller Überblick. Bochum 2000.

Nr. 32 Ansgar Belke: Lohnpolitik in der EWU - Stabilisierender oder destabilisierender Faktor? Bochum 2000.

Nr. 33 Elena Diaz Porta, Martin Hebler, Wim Kösters: Mercosur: Auf dem Weg zu einer Zollunion. Bochum 2000.

Nr. 34 Sonja Eckey, Markus Neimke: Regionale Integrationsdynamik aus Sicht der Neuen Politischen Ökonomie. Bochum 2000.

Nr. 35 Rainer Beckmann, Carsten Eppendorfer, Markus Neimke: Europäische Finanzmarktintegration und Wirtschaftswachstum. Bochum 2001.

Nr. 36 Jens M. Heine, Wim Kösters: Zur politischen Ökonomik der EWU: Vom Währungswettbewerb zum Monopol. Bochum 2001.

Nr. 37 Ansgar Belke: Too Big to Fail - Bankenkonkurs, ,Bailout' und Wählerstimmenkalkül. Bochum 2001.

Nr. 38 Rainer Beckmann, Jürgen Born, Wim Kösters: The US dollar, the euro, and the yen: An evaluation of their present and future status as international currencies. Bochum 2001. 